\title{
Kirjastolaitoksen puolustuspuheenvuoro!
}

Mikko Lahtinen (2010). Kirjastojen maa. Vastapaino, Tampere. 394 sivua.

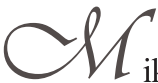

lee teoksessaan tärkeää itsestäänselvyyttä suomalaisessa yhteiskunnassa: yleisiä kirjastoja ja niiden kulttuuris-aatteellista taustaa. Kirjastoja on tutkittu Lahtisen tarkastelun perusteella yllättävänkin vähän, eikä niistä ole kirjoitettu aiemmin samanlaista analyysiä, jossa kuvattaisiin 250 kirjaston toimintaa, historiaa ja paikallisia tietoja. Teos on itsessään muodoltaan matkaromaani, joka perustuu tekijän ja hänen perheensä matkoihin eri puolille Suomea. Sen tekemisen virikkeenä on ollut M. A. Nummisen 1980-luvulla julkaisema teos baareista, mutta Lahtisen tarkastelussa mennään syvemmälle kulttuurihistoriallisiin kysymyksiin, ja sisältönsä osalta teos on myös huomattavasti perusteellisempi ja laajempi kuin Nummisen, lähes 400 sivuinen analyysi Suomen merkittävimmistä julkisista kirjastoista. Kokonaisuuden pohjalta rakentuu yleisempi kuva kirjastojen tilanteesta, kun kirjastolaitoksen tilanne on muuttumassa digitalisoinnin ja verkkopalveluiden seurauksena ja kun myös kuntarakenteen muutos on yhdistänyt ja osin supistanut kirjastoverkostoa. Kyse ei ole kuitenkaan mistään nostalgisesta katsauksesta menneeseen, vaan tarkastelu siitä, millaisia julkisia kirjastoja Suomessa on.

Kirja lähtee liikkeelle yleisten kirjastojen historiasta ja tarkastelun yleisestä luonteesta. Tämä taustoittaa jatkotarkastelua. Itse asiaan päästään jo seuraavassa luvussa, jossa käydään vaihe vaiheelta läpi Suomen monimuotoista kirjastokarttaa. Parin vuoden aikana tehdyillä matkoilla Lahtinen on tehnyt paikan päällä havaintoja kirjastojen arkkitehtuurista, kerännyt verkon kautta taustatietoja sekä muutenkin perehtynyt julkisten kirjastojen historiaan. Kirjasta välittyy monipuolinen, yksityiskohdissaan tunnistettava ja paljon informaatiota sisältävä kuvaus julkisten kirjastojen tilasta. Lahtinen tuntuu olevan kuvauksen perusteella itse kiireestä kantapäähän Kirjastojen mies: hän viihtyy erilaisissa kirjastoissa, osaa arvioida niiden toimivuutta käytännössä, tekee tarkkoja havaintoja ja liittää mukaan paljon historiallista taustaa, joka tuo lisävalaistusta aiheeseen. Itse asiassa kirjan kautta avautuu oma näkökulmansa myös Suomen kulttuurihistoriaan, ja lukiessa jää miettimään sitä, miten paljon julkisiin kirjastoihin liittyykään merkittäviä kulttuurisia puolia. Kirjastoarkkitehtuurin vaihtelevat virtaukset ja paikallisten merkkihenkilöiden rooli on myös lyönyt leimansa yleisten kirjastojen kehitykselle. Teoksen perusteella julkisten kirjastojen kartasto on monimuotoinen mosaiikki, jossa näkyy se, miten yhteiskunta on muutenkin kehittynyt.

Kirjastokartan selvitystyö tehdään teoksessa kronologis- maantieteellisessä järjestyksessä eli siten, että Lahtinen kuvaa aikajärjestyksessä kirjastoja, joissa hän on vieraillut matkojensa kuluessa. Matkat on toteutettu osin työmatkojen ohessa, osin siten, että liikkeellä on oltu useamman päivän ajan kiertämässä lukuisia julkisia kirjastoja tietyllä alueella, kuten Satakunnassa tai Pohjanmaalla.

Vaikka kirjan sävy on leikkisä, Lahtinen tekee kuitenkin tarkkaa työtä. Hän kuvaa ensin muutamalla vedolla paikkakunnan kulttuurihistorian kannalta merkittäviä henkilöitä, kirjaston arkkitehtuuria ja sen suunnitteluun liittyviä asioita sekä siirtyy sitten tarkemmin kirjaston sisäpuoliseen ilmapiiriin, aineistovalikoimiin ja mahdollisiin erityiskokoelmiin. Esimerkiksi Kuopion kaupungin kirjaston kokoelmista mainitaan Kuopion kymnaasin kirjaston kokoelmat, joissa on tiettyjä harvinaisuuksia. Vastaavasti Runebergin teoksista on laaja erityiskokoelma Porvoossa. Matkoilla ei juuri tapahdu mitään yllätyksellisistä, vaan Lahtisen annetaan tutustua rauhassa seurueensa kanssa kirjastoihin; poikkeus on Asikkala, jossa virkailija tiedustelee häneltä, onko hän kenties hakemassa kirjastonjohtajan paikkaa, kun tutkii niin tarkasti paikkaa. Useamman kirjaston yhteydessä Lahtinen törmää kuitenkin kuin vahingossa vanhoihin tuttuihinsa.

Vaikka Kirjastojen maassa käydään läpi suuri määrä yksittäisiä kirjastoja, Lahtinen pitää kokonaisuuden tiukasti näpeissään. Kirjaa lukee kiinnostunee- 
na eteenpäin ja monista yksityiskohdista yllättyy. Yllättävää on esimerkiksi se, että suomalainen kirjastojen tapakulttuuri on peräisin enemmän Amerikasta kuin Saksasta, eli se, että virkailijat antavat asiakkaiden selata rauhassa kokoelmia ja auttavat tarvittaessa. Toisaal ta selityksensä saa se, miksi moneen julkiseen kirjastoon on rakennettu kirja- tai lukusyvennys laajan kirjastotilan keskelle. Idea on alun perin Alvar Aallolta, joka käytti sitä Viipurin kirjastosta ja josta sen käyttö on levinnyt pitkin Suomea. Tällainen tasapainoilu arkisten yksityiskohtien ja vähän yleisempien taustatietojen välillä tekee kirjasta hauskan ja samalla runsaasti tietoa sisältävän esityksen.

Lahtinen on laatinut teoksensa taiten: yksityiskohtia on tarkistettu huolella ja kirjan yleisasu on viimeistely. Oma vaikutuksensa kirjan muotoutumiseen on varmasti Lahtisen omalla koulutustaustalla: hänen monipuolinen koulutuksensa filosofian, aatehistorian ja politiikan tutkimuksen kentällä tuo tarkasteluun analyyttistä otetta. Lisäksi hänen renessanssimainen suhteensa ympäröivään kulttuuriin tarkoittaa sitä, että häntä kiinnostavat lähes kaikki mahdolliset asiat maan päällä arkkitehtuurista historiaan ja musiikista taiteeseen.

Tyylillisesti Kirjastojen maa on kirjoitettu mukaansatempaavalla otteella. Kirjan perusteella Suomen värikkäästä kirjastokartasta hahmottuu tarkalla kädellä piirretty hallittu kuva. Lukija saattaa löytää oman elämänsä kannalta tärkeät kirjastot teoksesta. Matkakirjan muodosta seuraa myös se, että teosta voi lukea satunnaisesti eri puolilta, epäjärjestyksessä tai vaikkapa nope- asti silmäilemällä ja syventymällä enemmän itselleen tärkeisiin kirjastoihin. Kokonaisuutena Lahtisen työ tuo esille sen, että vaikka yliopistoilla ja erilaisilla oppilaitoksilla on omat kirjastonsa, julkisilla kirjastoilla on ollut ja on edelleen ennen kaikkea kulttuurilaitoksena tärkeä yhteiskunnallinen rooli. Monen kirjailijan tärkein paikka on ollut nuoruudessa kirjasto, samoin myöhemmin tutkimukseen suuntautuneen henkilön. Lahtisen tarkastelu tuo päivänvaloon tätä piiloista kulttuurista puolta ansiokkaalla tavalla ja avartaa kuvaa siitä, millainen instituutio julkinen kirjasto on ollut Suomessa ja mitä se on vielä tälläkin hetkellä.

Kirja päättyy monien maakuntakierrosten jälkeen kuin kesken pitkään Tampereella vaikuttaneen Helle Kannilan pohdintoihin julkisten kirjastojen palvelutehtävästä ja kirjastohenkilöstön roolista valikoimien kehittämisessä. Kannilan ajatukset ovat edelleen ajankohtaisia, mutta itsenäinen loppuluku olisi ollut paikallaan julkisten kirjastojen tulevaisuudesta, kirjan tilasta, verkkopalveluiden uudistamisesta jne. Nämä kysymyksethän tulevat muuttamaan kirjastojen luonnetta, ja esimerkiksi pääkaupunkiseudulla on tehty rohkeita avauksia kulttuurikeskusten suuntaan.

Olisi ollut kiinnostavaa kuulla Kannisen hengessä siitä, millaisia ajatuksia Lahtisella itsellään on kirjastojen kehittämisestä monikulttuuristuvassa Suomessa, mikä rooli kirjastoilla on hyvinvoinnin tuottajana ikääntyvässä yhteiskunnassa ja millaisia teknologisia uudistuksia maailmalla on tehty.

Kirjan perusteella betonisten rakennusten aika on ehkä osin ohitse ja kirjastolta haetaan enemmän yhteyttä ulkoiseen ympäristöön. Myös kirjastojenn valikoimat ovat uudistumassa. Mitä sitten esimerkiksi sähköiset lukulaitteet ja e-kirja tulee tarkoittamaan tulevaisuudessa kirjaston palveluiden, jää nähtäväksi, mutta ainakin toistaiseksi paperille painettu kirja ja sen lainaaminen on julkisten kirjastojen perustehtävä.

\section{Pekka Kuusela}

\section{Tulkinnan tueksi}

\section{Esa Poikelan ja Heikki Silven-} noisen artikkelissa Vapaa sivistystyö: tarve, tehtävä ja hyöty (3/2010) pääsi painokoneeseen taulukko (sivu 209), josta puuttuvat tulkinnan avaimet KYLLÄ ja EI. Oppilaitosten rehtoreilta kysyttiin, edellytetäänkö henkilöstöltä oppilaitoksen sivistystehtävän ja arvojen tuntemusta. "Kyllä", vastasi 87 prosenttia kansanopistojen, 78 prosenttia liikunnan koulutuskeskusten, 69 prosenttia kansalaisopistojen ja 67 prosenttia opintokeskusten johtajista. Vähiten arvojen tuntemusta edellyttivät kesäyliopistot (46 prosenttia rehtoreista).

Suomen 89 kansanopistosta runsas 40 on arvopohjaltaan kristillisiä, runsas 30 lasketaan grundtvigilaisiksi (sitoutumattomia ja toteuttavat alkuperäistä kansanopistoaatetta) ja loput ovat järjestöopistoja.

Kansalaisopistot ovat kunnallisia.

Yhdestätoista (11) opintokeskuksesta kuudella on puoluepoliittinen tausta, yhden takana on Evankelisluterilainen kirkko, yhden ammattiliitto ja kolme on sitoutumattomia. 